\title{
Vitiviniculture in the State of São Paulo (Brazil): Governance and technological strategies meeting market challenges
}

\author{
Adriana Renata Verdi ${ }^{1}$ and Malimíria Norico Otani ${ }^{2}$ \\ ${ }^{1}$ APTA, Gabinete do Coordenador, CEP: 01037-912 - Praça Ramos de Azevedo, 254, São Paulo, Brasil \\ 2 APTA, Instituto de Economia Agrícola, CEP: 01037-912 - Praça Ramos de Azevedo, 254, São Paulo, Brasil
}

\begin{abstract}
The viticulture in the State of São Paulo is expressive in the Brazilian context, as it holds the second place in planted area and third in production. Considering that the main practice is table viticulture, a good proportion of the grapes processed at the most relevant wine producer counties, come from the State of Rio Grande do Sul. The objective of this work is to characterize the current context of the vitiviniculture sector in the State of São Paulo, based on the main strategies of governance and technological strategies of governmental and private agents. For that, the work is fundamented on the results of the projects financed by FAPESP: "Revitalization of the vitivinicultural productive chain in the State of São Paulo: competitiveness, governance and sustainability" (2006/51949-7) and "The Territorial Governance Modalities in the State of São Paulo: coordination, territories, public policies and development" (2011/50837-9), besides following the Chamber for the Grape and Wine Sector and interviews with leaders of the sector. Therefore, the work approaches the major improvements of the more favorable governance of the vitiviniculture sector: formation of cooperatives, technological innovation, policies, public and private investment focused on building the identity of the wine from the State of São Paulo.
\end{abstract}

\section{Overview of viticulture in the State of São Paulo: Position in the national production, challenges and strategies}

The viticulture in the State of São Paulo is expressive in the Brazilian context, as it holds the second place in planted area and third in production. Considering that the main practice is table viticulture, a good proportion of the grapes processed at the most relevant wine producer counties, notably Jundiaí and São Roque, come from the State of Rio Grande do Sul.

Despite the current importance of wine bottling in the State of São Paulo and historical pioneering of the state in the Brazilian vitiviniculture, the wine production based on local grapes is relatively small, being a good part of the producers unaware of the current technological developments and maintaining their dependence to the southern grape production.

The focus the production of grapes suitable for in natura consumption, the lack of man power and knowledge about adaptation and vinification of new varieties, particularly vitis viniferas for processing, constitute the main reason for the lack of local grapes for winemaking.

Nevertheless, a handful of aspects such as a possible scarcity of southern grapes due to bad weather, the Intensification of wine tourism in the State of São Paulo and the emergency of a new category of capitalized wine makers allow us to foresee changes in the vitiviniculture scenario of the state.

\subsection{Position of the State of São Paulo's production in the Brazilian context}

Considering the prospect of Brazilian viticulture, the State of São Paulo holds the second place in planted area and third in grape production, mainly for the fact that the State of Pernambuco has a larger number of harvest seasons (Table 1).

In spite of the recent geographic expansion of the grape production in the national territory, to Mid-West and other South-East states, more than $80 \%$ of the 958 thousand tons of the Brazilian 2016 production is still concentrated in 3 states: Rio Grande do Sul, Pernambuco and São Paulo (Table 1).

According to the information present on IBGE Systematic Survey of Agricultural Production, from 2015 to 2016, the Brazilian grape production decreased $-36 \%$, and the State of Rio Grande do Sul presented the worst decrease, $-52,5 \%$ (Table 1 ).

This reduction in the volume of grape production at national level was not followed by the State of São Paulo, which registered an increase of $0.6 \%$.

The positive dynamics of the State of São Paulo in comparison with the negative national context allowed the improvement of the state production in the national scale. In fact, the state production reversed a previously continued decline in its participation in the total national production, evidenced during the 2013-2015 period. In 2013 , the participation of the state production was $12,2 \%$ of total national production, $10,2 \%$ in 2014 and $9,5 \%$ in 2015 , improved, however, to $14,9 \%$ in 2016 . On the other 
Table 1. National grape production and production of the most relevant states. 2013-2016 (ton).

\begin{tabular}{|l|l|l|l|l|}
\hline Estado & $\mathbf{2 0 1 3}$ & $\mathbf{2 0 1 4}$ & $\mathbf{2 0 1 5}$ & $\mathbf{2 0 1 6}$ \\
\hline RS & 808267 & 812537 & 876286 & 415739 \\
\hline PE & 228727 & 236767 & 237367 & 237367 \\
\hline SP & $\mathbf{1 7 2 ~ 8 6 8}$ & $\mathbf{1 4 6 ~ 7 9 0}$ & $\mathbf{1 4 2} \mathbf{0 6 3}$ & $\mathbf{1 4 2 ~ 9 6 7}$ \\
\hline PR & 79052 & 80910 & 64806 & 42750 \\
\hline BA & 52808 & 77504 & 77401 & 57240 \\
\hline SC & 57985 & 66106 & 69118 & 37344 \\
\hline SubTotal & 1399707 & 1420614 & 1467041 & 933407 \\
\hline Total Br & $\mathbf{1 4 1 7 6 7 7}$ & $\mathbf{1 4 3 6 0 7 4}$ & $\mathbf{1 4 9 2} \mathbf{1 3 8}$ & $\mathbf{9 5 8 6 7 6}$ \\
\hline
\end{tabular}

Table 2. Production of grapes in the State of São Paulo. Relevant regions -2015 (ton).

\begin{tabular}{|l|l|l|l|l|}
\hline Regions & $\begin{array}{l}\text { Common } \\
\text { Table } \\
\text { Grape }\end{array}$ & $\begin{array}{l}\text { Fine } \\
\text { Table } \\
\text { Grape }\end{array}$ & $\begin{array}{l}\text { Grape } \\
\text { Industry }\end{array}$ & Total \\
\hline Campinas & 41733 & 2390 & 22 & 44145 \\
\hline Itapetininga & 18108 & 20945 & - & 39053 \\
\hline Jales & 5090 & 18966 & 5 & 24061 \\
\hline Sorocaba & 3884 & 10485 & 768 & 15137 \\
\hline Sub Total & 68816 & 52786 & 795 & 122396 \\
\hline Outras & 5184 & 3845 & 520 & 9028 \\
\hline Total & 73999 & 56631 & 1315 & 131945 \\
\hline
\end{tabular}

hand, the participation of the State of Rio Grande do Sul decreased from $57 \%$ in 2013 to $43 \%$ in 2016 (Table 1).

According to the Subjective Survey of Institute of Agricultural Economics - IEA and Coordination of Integral Technical Assistance - CATI of Secretary of Agriculture and Supplies the State of São Paulo - SAA-SP, in 2015 the production of grapes in the state was 132 thousand tons, $56 \%$ of this volume being common varieties of table, $43 \%$ being fine varieties of table and just $1 \%$ represented varieties for industrial use (Table 2).

Concerning the spatial features of the viticulture area in the State of São Paulo, there are four traditional and important viticulture regions, presenting singular characteristics. Altogether, the regions of Campinas, Itapetininga, Jales and Sorocaba are responsible for the production of approximately $93 \%$ of the total state production of grapes (Table 2).

The region of Campinas is the most important producer of grapes in the state, with 44 thousand tons, amount that represents $33,5 \%$ of the total 2015 harvest. This region includes Jundiaí and consists in a traditional zone of production of grapes for table, especially Niagara Rosada. This variety is responsible for $94,5 \%$ of the grape production in the region of Campinas. Producing the total of 41700 tons, the region holds $56,4 \%$ of total production of grapes for table in the state.

The region of Itapetininga holds the second position with a total production of 39 thousand tons and a share of $29,6 \%$ of the total state production of grapes. In this region common varieties for fresh consumption are also predominant. However, there is a larger participation of fine varieties, with $54 \%$, while the common ones total $46 \%$ of the regional production of grapes.

The region of Jales is the third one in total production, with 24 thousand tons, representing 18,2\% of the grapes harvested in São Paulo in 2015. The region is historically engaged in the production of fine grapes for

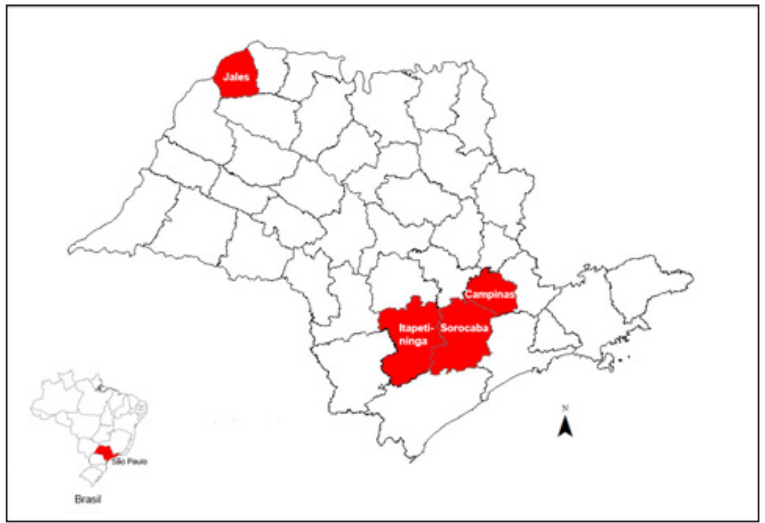

Figure 1. Most relevant Grape Production Regions in the State of São Paulo.

fresh consumption. Despite the fast growing tendency of common grape production, the fine varieties are still responsible for $79 \%$ of the total production in the region.

The region of Sorocaba holds the fourth position, with 15137 tons of grapes produced, representing $11,5 \%$ of the state total. There is a predominance of fine varieties, responsible for $69 \%$ of the region's production. Despite the relatively small volume of 767 tons, the region of Sorocaba stands out for producing $60 \%$ of the total of grapes produced for industrial use in the State of São Paulo.

The production of common and fine grapes for fresh consumption presents dense spatial concentration. The regions of Campinas, Itapetininga, Jales e Sorocaba are responsible for $93 \%$ of the grapes produced in the State of São Paulo, both common and fine varieties (Fig. 1).

The production of grape for the industry, spatially less concentrated, is not significant in the state.

\subsection{Major challenges for Vitiviniculture in the State of São Paulo}

Among the major bottlenecks for the production of grapes in the State of São Paulo, identified by the development of the vitivinicultural census within the project "Revitalization of the vitivinicultural productive chain in the State of São Paulo: competitiveness, governance and sustainability" financed by São Paulo Research Foundation - FAPESP (2006/51949-7), stand out: the scarcity of specialized professionals and the competition for space with other activities at the traditional grape production zones.

In fact, both aspects are associated, the emergency of other uses for agricultural areas within the traditional viticultural zones, located around the metropolitan area of the state, has contributed to an increase in land prices and to the emergency of new job offers in the industrial and service sectors. Therefore, the main grape productive zones are positioned on important urban and industrial expansion axis in the state.

The bigger economic return provided by the production of grapes for fresh consumption instead of industrial varieties, added to the specialization and quality achieved by the grape producers in São Paulo consist in the main reasons for the predominance of the farming for table grapes.

Therefore, while farmers managed to negotiate prices around $\mathrm{R} \$ 5,00$ for a $\mathrm{Kg}$ of Niagara Rosada in the 
region of Jundiaí in the 2015/16 harvest, the varieties for processing were bought by winemakers for $\mathrm{R} \$ 2,80$ the $\mathrm{KG}$ in the south of the country, including the costs with transportation and considering the tendency of falling in the production volume at national level.

Officially, the Industrial Grape Specific Norms Harvest 2015/16, published on January 15th, 2016 by the National Supply Company - CONAB, the minimum price to be paid for the $\mathrm{Kg}$ of the variety Isabel was fixed in $\mathrm{R} \$ 0,78$ while the variety Bordô had its price fixed in $\mathrm{R} \$ 0,93$ considering 15 grades Babo. Even the finer varieties, considering as reference the threshold of 18 grades Babo, the red varieties Merlot, Cabernet Sauvignon, Pinot Noir and Cabernet Franc had their minimum price fixed in $\mathrm{R} \$ 1,75$.

The threaten of lacking southern grapes, due to the bad weather, the growing demand for wine juice production, the intensification of wine tourism in the State of São Paulo and the emergency of a new category of capitalized wine makers point to a new scenario for the grape production focused on varieties for industrial use.

In spite of this tendency of changes in the grape production scenario in the State of São Paulo, the lack of information about the adaptability of varieties for processing, as well as the compatibility between rootstock and scion varieties, associated to the lack of information about these variables and about the final product have been inhibiting investments in grapes for the industry in the state.

Another aspect that has contributed to the lack of strategy and slow decision making in favour of industrial viticulture is the weakness of the governance of the vitiviniculture chain in the state. This broader question has hampered the better operationalization of the productive chain in the state.

Although the governance of the sector has been improving over the last years, the lack of representatives of some chain rings at the Chamber of Grape and Wine Sector of the State of São Paulo, the most articulated forum of leaders in the sector, compromises the proposition of strategies and collective projects to develop the sector and the areas. The frailty of the governance is a bottleneck that deserves attention from decision makers and entrepreneurs. Politically, the vitiviniculture in the state has much yet to develop.

The Pro-Wine Project, financed by FAPESP and coordinated by APTA, consolidated an institutional environment more favorable to the development of the vitiviniculture chain in the state, as it provides room for the articulation of the involved agents, essential stage to the creation of the Chamber of Grape and Wine Sector of the State of São Paulo by Secretary of Agriculture and Supplies the State of São Paulo. The more favorable governance stimulated the formation of cooperatives of wine producers and justified state investments in technical formation focused on the sector.

However, the results of the development of another FAPESP project "The Territorial Governance Modalities in the State of São Paulo: coordination, territories, public policies and development" (11/50837-9) recognized the poor balance between the representatives of the chain rings, which has led to "truncated governances" besides the geographic proximity between the agents which, allied to the tradition of the production in the joints, brought competition on between the main productive zones in the state [1].

This last aspect disclose the importance of the territorial dimension in this modality of sector governance and the need of establishing a plan for the vitiviniculture in the state in accordance with two approaches: a broader, the sector in the scale of the state; and another more specific, in the region scale, based on natural and human characteristics, particular for each of the different regions in the state.

\section{Overview of the viniculture in the State of São Paulo: Governance, public and private investment}

The first vitiviniculture census in the State of São Paulo, developed by the Pro-Wine Project in the period of 2008-2010, registered 123 wine producers and 16 bottling houses, spread among the four towns considered in the project: Jarinu, with 14 producers; Jundiaí with 95 producers and 3 bottling houses; São Roque with 13 bottling houses and São Miguel do Arcanjo with 14 producers [2].

In general, the 123 registered wine makers were small "artisanal" and responsible for approximately 400 thousand annual liters, while the bottling houses bottled 42 million liters per year [2].

Despite the classification, both wine producer and bottling house groups bear entrepreneurs with varied characteristics and strategies. Therefore, among the bottle houses, there is one which has made important investments in the production of grapes for processing, through tests with varieties and partnership research institutes. By farming 17 ha of grapes for processing, the bottling house grows only $4 \%$ of the raw material bottled in the house, but the quality of the product genuinely produced in the State of São Paulo has already stood out in the national wine market, taking part in the list of best Brazilian red wines at the XXII National Wine Assessment. This higher commitment to the production in the state of raw material from some bottling houses confirms how heterogeneous the group is.

In general, what connects this category is the predominant character of wine bottling, the strong organization among them, plus the aim of reducing the taxes over transport and distribution of goods (ICMS) to the wine of the state. In many cases, agents participate in more than one professional association, such as ANEVNational Association of wine bottle houses, Unions linked to FIESP - Federation of Industries in the State of São Paulo and ABRABE - Brazilian Beverage Association.

However, the most heterogeneous group is the wine producer one, mostly amassing "artisanal" wine makers. This category gathers agents at different technological levels, with different perspectives and investment capacity [3].

The majority is of small scale producers, at low technological level, resistant to innovation and nonformalized once not yet adequate to the norms. This category of producer manufactures artisanal "table" wines from american and hybrid varieties, especially common red wine, which represents, in average, more than $80 \%$ of the sales per productive unit. In general, the winemaker 


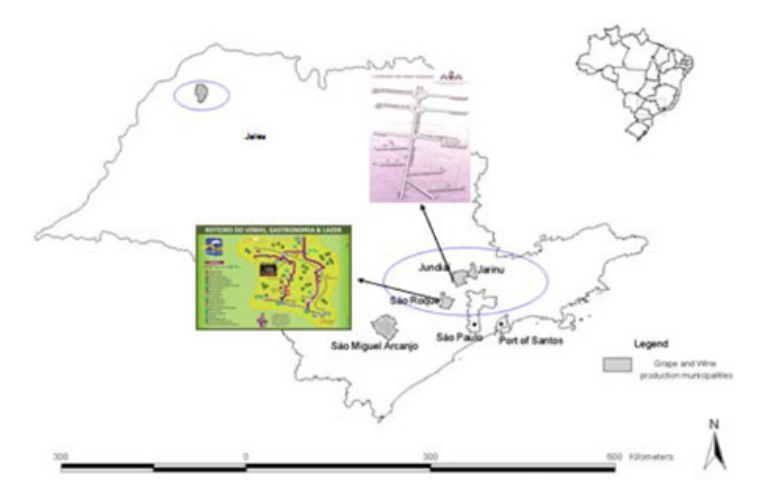

Figure 2. Main wine related tourism routes: Towns of Jundiaí e São Roque.

creates the blend of different kinds of wine, unique for each family, according to the taste of the traditional clientele, local and regional loyal customers.

Another group that stands out among the wine producers, already identified in the Pro-Wine Project, is made of small wine makers, generally part of the rural and wine related tourism routes (Fig. 2).

These start to organize associations and cooperatives and notice the oscillation in the price of southern grapes, the absence of contracts for the purchase and low quality of the grapes after the long transportation. This group is made of producers generally part of the rural and wine related tourism routes, aspect that stimulates association and cooperation initiatives.

The growing touristic demand enhances the commercialization of wine and, consequently, the vitiviniculture business potential, with new investments in the productive structure. Due to the conditions of informal and small, familiar production, the need for expansion and new markets has to overcome formalization and the organization of cooperatives.

Therefore, a new category of small wine producers emerges, bearing a high entrepreneurial potential, connected to the wine related tourism strategies and to local and regional cuisine, inherited from European colonization.

In the last five years, there has been the emergency of two cooperatives: the first, coming from the Cooperative of Artisanal Wine Producers of Caxambu/Jundiaí AVA and, the second one coming from the Association of vitiviniculture producers from Vinhedo - AVIVI. Therefore, the wine cooperatives had been through different forms of prior organizations, generally by association.

More recently, emerges another category of producer in the vitiviniculture field on the state: producers with no tradition, high investment capacity, including for the farmimng of fine wine grapes, especially concentrated in the region of Serra da Mantiqueira, a traditional coffee production area. For its geographic proximity, practically an extension of the State of Minas Gerais, this wine makers buy seeding and have technical support from EPAMIG - Agricultural Research Company of Minas Gerais, besides, they can rely on the consultancy from highly internationally experienced professionals.

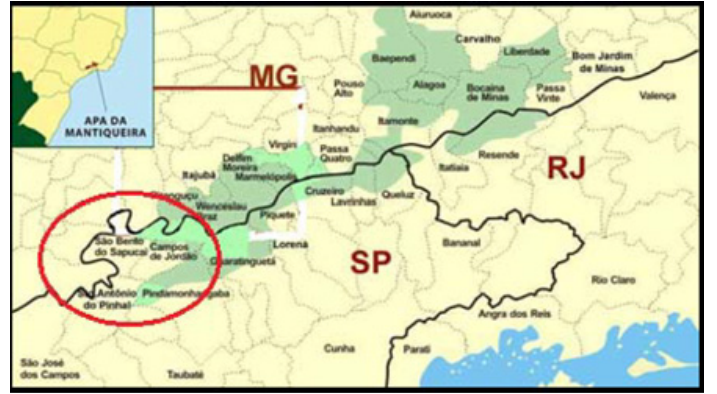

Figure 3. São Paulo's part of Mantiqueira: area privileged by the new wine entrepreneurs.

\subsection{New entrepreneurs in the vitiviniculture of the state: A change in the paradigm}

Undoubted ly, a paradigmatical change in the vitiviniculture of the state in process: the production of fine wine made from grapes grown in the state.

This new category of winemaker gathers producers with no tradition but high technological level, excellent technical assistance and investment capacity to develop high quality products made from their own fine grapes.

The new entrepreneurs of the vitiviniculture in the state are located at the south-eastern portion of the state, mainly composed of the mountains and hills of Serra da Mantiqueira. Two aspects explain the expectative about the region: 1 - the harvest in the winter, possible due to double pruning: a formation pruning, after the harvest and another production pruning. 2 - The second aspect is related to the altitude climate - 1100 to 1300 meters high - which contributes to the thermal amplitude providing positive influence over the grape cycle (Fig. 3).

The pioneers of this new model are: the winemakers Guaspari, from Espírito Santo do Pinhal, Casa Verrone, from Divinolândia, Entre Vilas and Villa Santa Maria, from São Bento do Sapucaí.

The Guaspari winemaker, founded in 2006, financed by capitals from the mining sector, earned its first commercial harvest in 2012. The property of 800 ha of agricultural land concentrates vineyards of 50 ha: Vista da Serra, Vista do Vale and the highest one, Vista do Chá, more than 1300 meters high. The vineyards were divided in 12 different terroirs, delimited by their specific microclimate, being the main varieties: 17 ha of Syrah, 8,5 ha of Sauvignon Blanc, 8 ha of Chardonnay, 6 ha of Pinot Noir, 5 ha of Cabernet Sauvignon, 4 ha of Viognier, 2,5 ha of Cabernet Franc.

At Casa Verrone, the investments were financed by the agricultural input sector capitals. The wine house holds two vineyards of total 20 ha: in the town of Itobi are grown the red wine varieties, mainly Syrah, Cabernet Sauvignon and Cabernet Franc, with summer harvest and altitude of 860 meters, while in the town of Divinolândia are grown the varieties Sauvignon Blanc for the production of white wine and the varieties Chardonnay and Pinot Noir for the production of Sparkling Wine, through summer harvest and altitude of 1300 meters.

Casa Verrone relies on the support from EPAMIG and Brazilian Sommelier Association - ABS. The wine making, held at EPAMIG, was awarded as the best Chardonnay at the Brazil great wine tasting. According to an interview published by Gazeta do Rio Pardo on 
07/Feb./11, Verrone aims the production of 300 thousand bottles per year, with the farming of new areas [4].

The wine house "Entre Vilas" adopted the organic system of farming for the varieties: Cabernet Sauvignon, Cabernet Franc, Syrah, Malbec and Pinot Noir. Its wines do not use pesticides, sulfites and do not go through chaptalization (sugaring), therefore they are considered natural wines, an important market distinction.

In this new context, brought by the new investors of Serra da Mantiqueira, it is valid to mention the recent investments of the Carbonari in the town of São Bento do Sapucaí.

\section{Recent public and private strategies}

Considering the challenges of the vitiviniculture in the State of São Paulo, mainly the lack and high cost of man power, the lack of knowledge about the adaptation of varieties for industrial use as well as about the compatibility between scion and rootstock, besides the lack of socioeconomic information about the grape and wine producers, it is valid to highlight public and private efforts aiming de development of activities in the state.

In a certain way, the agent's strategies demonstrate their perspectives in relation to the vitiviniculture in the state.

\subsection{Private and public research}

The two projects in which this work is based on, financed by FAPESP, neared public research institutions around the state's vitiniculture sector challenges and brought important contributions.

Aiming to develop the register of the vitiviniculture in the state, the structure of the wine productive chain, new experiments with varieties of grapes for industrial use and the classification of the produced wines according to the current norms, the project "Revitalization of the Vitiviniculture Chain of São Paulo" was developed. The project amassed researchers from Institute of Agricultural Economics - IEA, Agronomic Institute - IAC and Institute of Food Technology - ITAL of Agency Paulista Agribusiness Technology - APTA and from Campinas State University - UNICAMP.

Another collective project financed by FAPESP "The Territorial Governance Modalities in the State of São Paulo: coordination, territories, public policies and development" had researchers from Universidade Estadual Paulista - UNESP/Campus de Rio Claro and from APTA's IEA. The project contributed to the knowledge about the governance of the vitiviniculture sector in the State of São Paulo.

In relation to the challenges of lack and cost of specialized manpower for the viticulture in the state, it is valid to highlight the studies developed by CEA/IAC/APTA - Agricultural Engineering Centre of Agronomic Institute of Agency Paulista Agribusiness Technology. This research line has achieved improvements focused on the paradigm change in the production of raw material for vitiviniculture.

This way, the work of Santos suggests an expansion of the farming frontiers and the use of partially or totally mechanized processes of vine tree management, as a way of facilitating and turning viable the local production a lower cost, able to supply the already existent industrial demand. When considering the benefits of adopting mechanized pruning on the cost of production and pace of operation, CEA/IAC/APTA invested in the assessment of the impact of this innovation on the behavior of the varieties and on the quality of the final product. Besides the development of a vine-tree pruner for application, researchers were concerned with the analysis of the parameters for a correct mechanization based on the local, the plant condition, the soil and the social profile of producers [5].

For that, were implemented experiments with the European varieties Cabernet Franc, Merlot and the hybrids IAC-138-22 "Maximo", IAC-166-31 "Rainha" and IAC 21-14 "Madalena" in Jundiaí in 2011 and 2012. The varieties were established over four different rootstock trees: IAC 766-Campinas, IAC 572-Jales, Ripária do Traviú e SO4 and grown on espalier $(2,3 \times 1,5 \mathrm{~m})$ [5].

To the present day, the analysis of two harvests provided positive results, that is, the application of mechanized pruning in traditional vineyards cause minor oscillation in the quality of grapes [5].

Another research line, developed by APTA units has aimed at detecting climate tendencies in series of air temperature and rain precipitation at three localities in the east of the State of São Paulo, mainly Campinas, Jundiaí and Monte Alegre do Sul, with the objective of assessing the impact of this variation on agrometeorological indexes frequently used to indicate favorable areas for the production of wine grapes [6].

Beyond these lines of research, it is valid to highlight the studies aimed at assessing the influence of rootstock trees "IAC 766 Campinas" and "106-8 Mgt Ripária do Traviú" over the physical-chemical features of the wine must and the wine from grapes "IAC 116-31 Rainha," "IAC 21-14 Madalena" and "BRS Lorena" [7].

More specifically focused on the predominant variety in the region of Jundiaí, with a high market potential and potential for winemaking, stand out the studies about the norms for the DRIS - integrated system for diagnosis and recommendation, and the critical nutrient levels for the vine tree "Niagara Rosada" [8].

In addition to the more contemporary strategies, the creation of the AGROPOLO of Campinas, this involves partnerships with research institutes from the AGROPOLIS from Montpellier, France. The first project at AGROPOLO level, approved by FAPESP, involves the realization of a workshop for the discussion of the vitiviniculture context in the state, together with the most important leaders in the sector.

From this perspective, also stand out the tests with varieties developed by producers in partnership with research institutes APTA and EPAMIG. Among the main results related to the adaptation of varieties for industrial use in the state, it valid to mention:

- in the traditional locations: fine wine varieties Syrah in Louveira and Cabernet Franc in São Roque, plus hybrid BRS Lorena in São Roque.

- in the recently occupied locations: the fine wine varieties Syrah, Pinot Noir and Chardonnay in Divinolândia and Santo Antônio do Pinhal. 


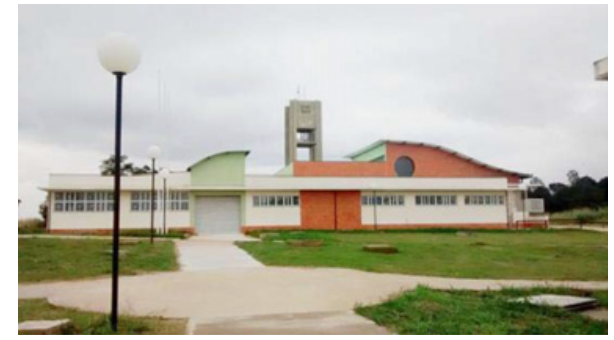

Figure 4. New investments in the Vocational School Benedito Storani - Jundiaí/SP.

\subsection{Public and private investments}

Since 2010, Federal and State governments have intensified the investments, mostly in technical and higher formation in oenology at the the traditional regions of Campinas and Sorocaba, notably in the towns of Jundiaí, Campinas and São Roque. Such investments contribute to the set-up of Vitiviniculture Productive Arrangement.

At national level, the IFSP - Education, Science and Technology Federal Institute of São Paulo, federal educational autarchy, Campus São Roque, open in August, 2008 offers vocational courses and four higher degree courses: Bachelor degree in Business Administration, Degree in Biological Science, Technology in Environmental Management and Technology in Viticulture and Oenology.

The course "Technology in Viticulture and Oenology" is one of the most recent ones at the unit and is based on four technological axes: basic formation; viticulture with oriented theoretical and practical soil management and conservation, grape farming, management of plagues and diseases; oenology which is related to the processing of the raw material focused on the wine making, and harmonization; at last, management with lessons focused on business administration, commercialization and logistics.

The state administration has also made significant investments in the vitiviniculture in the region of Campinas.

Founded in 1959, in Jundiaí, the Vocational School Benedito Storani has been through significant transformations, being currently connected to Paula Souza Center and to the Secretariat of Economic Development, Science and Technology and Innovation of the State of São Paulo. There are expectations for the creation of the courses on Oenology and Viticulture. To operationalize these courses, in 2014 began the process of construction of two big structures, the laboratorial part and the industrial part, with both market-oriented and professionalizationoriented objectives. The investment from the state administration is already over R \$ 8 million (Fig. 4).

Beyond the technical qualification of manpower focused on the state and regional vitiviniculture, the higher expectations are that the vocational school operationalize the production of small scale producers at low technological level and become a reference at the dissemination of innovation for the commercial use of wine grape processing leftovers and the production of juice.

The Government of the State of São Paulo, via the Watershed Program developed by CATI/SAA-SP, financed by the World Bank, contributed with financial resources for

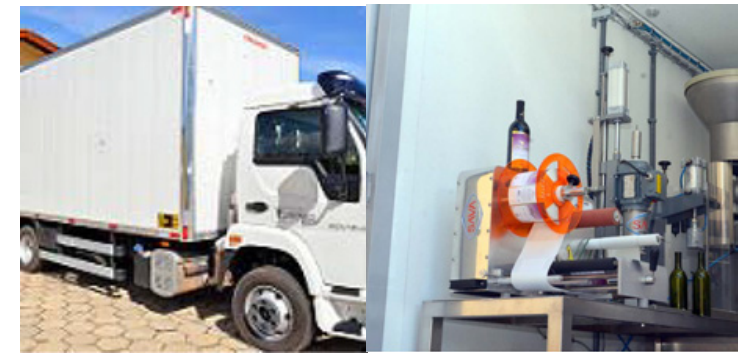

Figure 5. AVA Cooperative Mobile Bottling - Jundiaí/SP.

the realization of the mobile filling of AVA - Cooperative of Artisanal Wine Producers of Caxambu/Jundiaí. The recent cooperative comes from the Association of Artisanal Wine Producers of Caxambu/Jundiaí created 12 years ago and currently counts on 20 cooperates. AVA mobilized actions from public institutions and had as main achievements the formalization of production and regularization of mobile bottling along MAPA, plus the resources of Watershed for the purchase of the necessary equipment.

The effective regularization and operationalization of the mobile bottling took place in two stages:

-the first one dealt with the formal demand within the Chamber for the Grape and Wine Sector in the State of São Paulo and, consequently within the Federal Chamber for the sector. The pioneering of the demand deserved special attention from the Ministry - MAPA.

-as a cooperative, the secong stage dealt with the project presentation within CATI/SAA-SP aiming at earning finance for the Program Watersheds II "Access to the Market", through World Bank resources.

Further to the authorization from the Ministry - MAPA, AVA earned the finance of around R\$ 400 thousand from the Program Watersheds for the purchase of the lorry and the necessary equipment needed to the operationalization of mobile bottling (Fig. 5).

Considering total investment, AVA contributed with $30 \%$ of the budget as counterpart. The capacity of production of the system, pioneer in Brazil, is of 700 bottles per hour. In the referred structure, AVA has already included the equipment necessary to produce sparkling wine from the variety Niagara Rosada, an important mid-term bet of the cooperative.

Another recent investment in infrastructure for the sector was the installation of the Laboratory of Beverage Testing, from School of the National Service of Industrial learning - SENAI Professor Euryclides de Jesus Zerbini, which stands in 278 square meters, in the town of Campinas. Launched in 2014, the enterprise was projected to meet the needs of companies' producers of fermented, alcoholic, non-alcoholic, distillate beverages and vinegar. Equipped with highly technological infrastructure, the lab offers technical and technological specialized support to producers. Its creation was brought up after a demand from the Union of Grape and Wine from Jundiaí and São Roque.

\section{Final considerations}

The viticulture in the State of São Paulo is important in the national context, yet it mostly focused on the production of non-fine varieties, being most of the processed grapes from the State of Rio Grande do Sul. 
Among the main factors that justify the focus on the production of grapes for in natura, there are: the better profitability of these varieties, the lack of specialized manpower and the lack of knowledge about the adaptation and winemaking of new varieties.

The movement articulated by the Wine Institute SPVINHO in favor of the development for the vitiviniculture productive chain in the State of São Paulo, mostly the ProWine Project, financed by FAPESP, consolidated a more favorable institutional environment to the development of the vitiviniculture productive chain in the State of São Paulo by providing the base for the creation of the Chamber for the Grape and Wine Sector.

On the one hand, the more favorable governance stimulated the formation of cooperatives and generated new investments from the producers in the state. On the other hand, it stimulated new research and justified state investment in the technical formation and generation of knowledge for the sector.

However, the results of the development of the project "The Territorial Governance Modalities in the State of São Paulo: coordination, territories, public policies and development" also financed by FAPESP, recognized the development of "truncated governances" between the members of the Chamber for the Grape and Wine Sector and revealed the importance of the territorial dimension in this modality of sectorial governance.

Among the groups of producers recognized for researches in the current scenario, stand out the new entrepreneurs of Serra da Mantiqueira. These new wine entrepreneurs, allied with the potential return from the public investment during the last five years outline a new paradigm for the vitiviniculture in the state.

However new actions are made necessary:

a) Considering the weaknesses of the current sectorial governance and the imbalance between participations, it is necessary to stimulate the representatives of the rings not-participating the Sectorial Chamber and strengthen the role of less prepared and organized agents.

b) Considering the competition between productive regions, it will be necessary to strengthen the territorial governances of the main vitiviniculture groups, through a plan focused on different scales, according to a broad view on time and space.

\section{References}

[1] A.R. Verdi, M.N. Otani, M.C.M De Souza. Territorial governance of sectorial chambers in São Paulo State. VI Congresso SIAL. Florianópolis - SC (2013)

[2] A.R. Verdi, M.N. Otani, M.L. Maia, C.E. Fredo, A.L. R. De Oliveira, J.L. Hernandes. Panora da vitivinicultura paulista, Censo 2009. Rev. Informações Econômicas, SP, v. 41, n. 11, nov. (2011)

[3] M. N Otani, A.R. Verdi, C.E. Fredo, M.L. Maia, M.C.M De Souza. Processo de consolidação da vinicultura artesanal: um estudo de caso no entorno metropolitano de São Paulo e Campinas. Informações Econômicas, SP, v. 43, n. 4, jul./ago. (2013)

[4] Gazeta do Rio Pardo. Enfoque http:// gazetadoriopardo.com.br/vcolunas/169/Enfo que.html (2011)

[5] A.O. Santos, S.E. Pereira, C.A. Moreira. Qualidade físico-química da uva e perfil sensorial vínico para diferentes cultivares de videira submetidas à poda mecanizada. Rev. Bras. Frutic. Jaboticabal -SP, v.37, no.2, Abril./Junho (2015)

[6] L. Bardin-Camparotto*; G.C. Blain; M.J. Pedro Júnior; J.L. Hernandes; P. Cia A. Climate trends in a non-traditional high quality wine producing region Tendências climáticas em uma região não tradicional de produção de vinhos de alta qualidade. Bragantia. vol.73, no.3, Campinas Julho/Set. (2014)

[7] M.J.R. da Silva, M.A. Tecchio, M.F. Moura, L.T.brunelli, U.M. Imaizumi, W.G. Venturini Filho. Composição físico-química do mosto e do vinho branco de cultivares de videiras em resposta a portaenxertos. Pesq. Agropec. Bras. Brasília, v. 50, n. 11, p 1105-1113, nov. (2015)

[8] L.A.J. Teixeira, M.A. Tecchio, M.F. Moura, M.M. Terra, E.J.P. Pires. Normas DRIS e níveis críticos de nutrientes para videira 'Niagara Rosada' cultivada na Região de Jundiaí-SP. Rev. Bras. Frutic. Jaboticabal SP, v. 37, n. 1, p. 247-255, Março (2015) 